\title{
Implementing plagiarism awareness workshop to nursing faculty members, Damanhour University
}

\author{
Yaldez Khairy Zein Eldin , Lucy Abu El Ela \\ Faculty of Nursing, Damanhour University, Damanhour, Egypt
}

Received: May 22, 2016

DOI: $10.5430 /$ jnep.v7n1p124
Accepted: August 22, 2016

Online Published: September 11, 2016

\begin{abstract}
Background and objective: Plagiarism is defined as intentionally and without agreement presenting someone else's ideas or words, as one's own work. Plagiarism by academics occurs due to the growing pressure to publish research, in addition to increasing burden to publish in high-impact top-tier journals. The present study aims to implement a plagiarism awareness workshop to Nursing Faculty members to introduce the plagiarism concept as one of research misconducts and to compare between knowledge of Nursing faculty member pre and immediately post workshop.

Methods: The study was conducted at Faculty of Nursing, Damanhour University. Subjects: The study subject included 51 working full time nursing faculty members who agreed to participate in the workshop. Study instrument: the researchers had developed a self-administered questionnaire which was designed to assess the nursing faculty member's perceptions of plagiarism. Results: The current study results showed that $55 \%$ of participants have fair knowledge about plagiarism as compared to $11.7 \%$ whom knowledge level is poor. Also, it was found that the highest percentage of participants (96.1\%) was among those who refused plagiarism post workshop with a significant difference $(p=.001)$ between responses pre and post workshop. Moreover, the highest median of change (19.23) was among age group 40-50, while the lowest median (3.23) was recorded for the age group 30- with a significant difference between groups $(p=.002)$. Regarding the participants' titles, the highest median (20.69) was among assistant professor while the lowest median (-1.72) was among clinical instructor with a significant difference recorded $(p$ $=.050)$.

Conclusions: The current study findings concluded significant positive changes in the level of knowledge of the participants after implementation of workshop.
\end{abstract}

Key Words: Plagiarism, Research misconduct, Academic dishonesty, Egyptian researches

\section{INTRODUCTION}

Researches are performed to find the truth, and therefore amongst the basic principles of responsible research conduct, honesty is the major and most important one.$^{[1]}$ Nowadays, scientific writing and professionalism are not considered easy tasks and they are hard processes as they demand visibility and conciseness. Meanwhile, accuracy and integrity are fundamental components of scientific writing. Thus, valuable scientific writing should be characterized by obvious expression and precision of what is being reported. ${ }^{[2]}$ In scientific writing, perhaps the most usually recognized unethical conduct is plagiarism.

Plagiarism is not considered a new matter; however increased publicity and advances in disclosure strategies mean that the possibility of plagiarism is more likely to be discovered. ${ }^{[3]}$

\footnotetext{
*Correspondence: Yaldez Khairy Zein Eldin; Email: yaldez2001 @ hotmail.com; Address: Nursing Administration Department, Faculty of Nursing, Damanhour University, Egypt.
} 
Plagiarism is defined as intentionally and without agreement presenting someone else's ideas or words, as one's own work. This ranges from minor cases, such as messy paraphrasing, to major occurrences, such as intentional word-for-word copying of someone else's work without proper acknowledgment. ${ }^{[4,5]}$ Different acts are considered plagiarism such as failures either to cite quotations and borrowed ideas, or to enclose borrowed language in quotation marks, or to put summaries and paraphrases in your own words, or to submit someone else's work as your own. ${ }^{[6]}$ It also includes the unauthorized use of ideas or unique methods obtained by a privileged communication. ${ }^{[3]}$ Another form of plagiarism is self-plagiarism which is known as duplicate publication, which is, the publication of all or parts of one manuscript in separate journals. ${ }^{[7]}$

Plagiarism by academics occurs due to the growing pressure to publish research, in addition to increasing burden to publish in high-impact top-tier journals. ${ }^{[8,9]}$ Sometimes, plagiarism is conducted as a result of urgent dead time or because of poor academic writing skills especially if the writing language is not the native language of the author resulting in papers that are not clearly written and have grammatical errors and consequently rejected by journals' reviewers. ${ }^{[10-12]}$ Another cause for plagiarism could be the major driver is the ill-fated system of quantitative measurement of scientific output, which has led to an intense increase of low quality researches, and a parallel increase of scientific journals, especially in the area of life science. ${ }^{[5]}$

Many perceived barriers were found to change around the management of plagiarism in faculties. These barriers include: a) the willingness of faculty members to process a case of doubted plagiarism due to the time and load involved in proving the plagiarism; b) the reluctance to become the person who differs from others in common practice to "turn blind eye" to some slight cases of plagiarism; c) the perception that the university is unwilling to deal with suspected plagiarism and consequently the effort expended by faculty members is likely to be useless in terms of preventing or punishing plagiarism; d) a fear of jeopardizing collegial relationships with students by seeming and becoming severe due to an emphasis on reducing plagiarism; e) a concern of damaging the international reputation of the faculty or university; f) and a further concern that such damage to reputation may result in reduced international enrolments. ${ }^{[13]}$

To overcome the previously stated obstacles, open discussions are required in universities among administrators, faculty members, assessors, quality assurance professionals and students to address plagiarism. Moreover, their aim should be to develop common language addressing plagia-

Published by Sciedu Press rism. It therefore seems appropriate to involve a range of stakeholders within a study. Preventive measures addressing plagiarism can be promoted at all levels involving activities undertaken by a range of staff at course, school and university level. ${ }^{[1]}$ The majority of universities all over United States of America and Europe put clear rules to prevent plagiarism such as keeping good notes, referencing on the source material and avoiding overuse of direct quotations. It is always better to paraphrase and use general statements to support arguments. ${ }^{[14,15]}$ Also, Editors, reviewers, professionals and tutors should be alert to the possibility of plagiarism, rigorously check sources and consider the use of plagiarism detection software. ${ }^{[16]}$

As advanced technology makes it easy to plagiarism to be committed it make it easy to be caught as well. ${ }^{[5]}$ External reviewers are recruited by reputable professional journals to ensure integrity and standards. Reviewers check the article accuracy, being up-to-date, promote academic standard and encourage evidence-based practice. There are many ways of detecting plagiarism. Software such as Turnitin is commonly used in the UK. Essays can be put through this system, which indicates the percentage match found on the internet and the sources of such information. ${ }^{[8]}$

Recently many international studies searched for research misconduct generally and plagiarism especially, for instance, Fanelli (2009) ${ }^{[17]}$ conducted a meta-analysis of survey data on scientific misconduct, it was concluded that $34 \%$ of researchers admit questionable research practices and $2 \%$ admitted to have falsified research. Also, Broome and colleagues (2010) studied the ethical concerns of nursing reviewers in an anonymous online survey of 1,675 nursing journal reviewers. The researchers found that $21 \%$ expressed concerns about duplicate publication or other forms of plagiarism. ${ }^{[18]}$ In Egypt, Belal and Springuel ${ }^{[19]}$ studied the research in Egyptian Universities without discussing the plagiarism issue. Darrag, Youssri and Badreldin (2012) studied academic dishonesty among students in higher education, the researches found that there are significant levels of academic dishonesty and the higher practice was working cooperatively on individually assigned tasks. ${ }^{[20]}$ Other efforts, plagiarism is discussed on the daily journals, for instance, Al-Masry Al Youm published an article about plagiarism in Egypt in which the journal interviewed the head of Egypt's Academy of Scientific Research and Technology who reported that Egypt has the highest rates of research plagiarism. He also stated that causes of this high percentage of plagiarism could be a lack of writing skills among many research authors and the lack of modern plagiarism detection software. ${ }^{[21]}$ Furthermore, Elyan (2008) wrote that the lax rules governing plagiarism and sometimes its absence in Egyptian univer- 
sities as well as the promotion and advancement of known plagiarizers are major causes for high plagiarism rates in Egyptian universities. ${ }^{[22]}$ In addition to Khaled (2008) who interviewed the Dean of Beni Suef university and he reported that from the causes of plagiarism in Egypt could be the lack of funds and resources for research. Also, he stated that low academic salaries could be considered as a cause. ${ }^{[23]}$

To the knowledge of authors, there has been no empirical research that has either investigated plagiarism knowledge among faculty members or examined some of its causes in Egypt. Giving the fact that Egyptian academics are required to publish in high impact factor journals and the new bylaws $^{[24]}$ issued in 2016 governing promotion for all tenure academics affiliated in private or public universities set as one requirement to check all presented papers against plagiarism and take a plagiarism free report from the centralized Egyptians Universities libraries. Hence, the current study is conducted to identify the level of knowledge that Faculty of Nursing staff members have on plagiarism and to raise their awareness to this concept that is to somehow new for them.

\subsection{Aim of the study}

The present study aims to introduce the plagiarism concept through one-day workshop and to compare between knowledge of Nursing faculty member pre and immediately post workshop.

\subsection{Study questions}

The study question is: Is there a significant difference in knowledge about plagiarism among Nursing faculty staff members before and after implementation of a one-day workshop?

\section{Materials \& Methods}

\subsection{Research design}

A quasi experimental research design was used to conduct the study.

\subsection{Setting}

The study was conducted at Faculty of Nursing, Damanhour University which is considered new faculty with active young researchers. Also, both researchers work in the previously mentioned setting.

\subsection{Subjects}

The study subject included 51 working full time nursing faculty members who agreed to participate in the workshop.

\subsection{Study instrument}

After a thorough review of literature, ${ }^{[25-27]}$ the researchers had developed a self-administered questionnaire which was designed to assess the nursing staff member's perceptions of plagiarism.

The instrument was composed from three parts:

- The first part consisted of socio-demographic professional profile in six questions.

- The second part consisted of eleven questions in which the faculty members were asked to answer questions concerning their perceptions about plagiarism, the seriousness of plagiarism, and the frequency in practices involving plagiarism. The eleven questions were on 4 points likert scale ranging from $1=$ strongly disagree to 4 = strongly agree.

- The third part composed of two open ended questions on the definition of plagiarism and measures to avoid it.

\subsection{Methods}

The study was conducted as follows:

(1) An official permission was obtained from the Dean of the Faculty of Nursing, Damanhour University.

(2) The study instrument was designed by the researchers after extensive review of related literature and its content validity was tested by five experts in the field of the study. Accordingly, the necessary modifications were done.

(3) Reliability of the tool was done using Cronbach's Alpha (0.856).

(4) A pilot study was carried out on $10 \%$ of the subjects ( $n=5$ Nursing faculty members). They were conveniently selected and were not included in the study subjects. It was used to ensure the clarity of the questionnaires, identify the obstacles and the problems that may be encountered in data collection and estimate the time needed to fill the questionnaires.

(5) Pretest was performed consequently the workshop day was planned.

(6) Steps of application of the one-day workshop:

- Selection of Intended Learning Outcomes for the workshop based on the participants' needs and aim of the study.

- Choosing the relevant active teaching strategies according to the information presented.

- The workshop day was decided and the announcement was done prior to the workshop day by one week at least by hanging advertisement on the faculty's building walls and by using the "whatsapp" group of the faculty to notify about the date, time and place of workshop. 
- Each day consisted of 25 or 26 participants, they were divided into 5 groups and each group had 5 members.

- The teaching strategies carried out during the workshop were: brainstorming, small group discussion, case studies about paraphrasing, and role play.

- The outlines of the workshop were:

- Ice breaking and introduction

- Definition of research misconduct

- Definition of plagiarism

- Factors that leads to Plagiarism

- Types of plagiarism

- Causes of plagiarism

- Consequences of plagiarism

- Self Plagiarism

- Paraphrasing correctly

- How to avoid plagiarism

(7) After completion of the workshop, participants were given the post test to answer it.

(8) The same planned workshop was conducted on two different days. Due to the unavailability of participants and their busy schedules, the first workshop was done at the summer holidays (September 2015) and the second was held on the mid year holidays (JanuaryFebruary 2016).

\subsection{Ethical considerations}

(1) An informed consent was obtained from all staff after explanation of the aims of the study.

(2) Confidentiality, anonymity and privacy were assured by not asking about their names on the test either pre or post. Instead to ensure the encoding, the researchers before starting the workshop numbered both pre and post tests with the same number and gave them to the participants.

(3) Participation was on voluntary basis.

(4) Participants were given the right to withdraw from the study at any time without any drawbacks.

\subsection{Statistical analysis}

After data were collected it was revised, coded and fed to statistical software SPSSIBM version 20. All statistical analysis was done using two tailed tests and alpha error of 0.05 . All discrete scores for items concerning plagiarism were summed together and average score were calculated. The total score was then categorized into accepting and refusing plagiarism based on likert scale percentile method as those who had a score less than 27 , were considered accepting plagiarism, others were considered refusing it. To identify

Published by Sciedu Press the efficacy of intervention, score change percentage was calculated by dividing absolute change from baseline to after intervention score by baseline score then multiply by 100 . The awareness scale was divided into 3 categories (poor, fair $\&$ good) based on the range methods which were used as the score range $=36-9=27$ the score cutoff range is $27 / 3$ $=9$ so Poor will be between $9-(9+9)=9-18$, Fair between $18-(18+9)=18-27$ Good 28-36. Descriptive statistics in the form of frequencies and percent were used to describe the categorical data variables while scale data were expressed by mean and standard deviation while score change percentage were expressed as median with range due to skewed nature. To test for differences at each scale item frequencies between two study phases, Mc-Nemar test for repeated categorical measures was used. Paired $t$-test was used to compare overall mean scores before and after applying intervention. For other items and due to multichotomus response categories, test of marginal homogeneity was used to compare answers before and after intervention. Median score change percentage were compared between different sample characteristics using Kruskal-Wallis test.

\section{RESULTS}

As shown in Table 1, the highest percentage (60.8\%) of participants was in the group age 40-50 while the lower percentage (13.7\%) was aged 20 to less than 3 , with an average age 38.2. All participants were female. Regarding their title, the lecturers received the highest percentage $(66.7 \%)$ while clinical instructors and demonstrators received the lowest percentage equally $(3.9 \%)$.

Table 1. Demographic characteristics of Faculty of Nursing staff member who attended the workshop $(n=51)$

\begin{tabular}{lll}
\hline Demographic data & No & \% \\
\hline Age (years) & 7 & \\
$20-$ & 13 & 13.7 \\
$30-$ & 31 & 25.5 \\
$40-50$ & $38.2 \pm 6.4$ & 60.8 \\
Mean \pm SD & & \\
Gender & 51 & 100.0 \\
Female & & \\
Title & 2 & 3.9 \\
Clinical Instructor & 2 & 3.9 \\
Demonstrator & 6 & 11.8 \\
Assistant Lecturer & 34 & 66.7 \\
Lecturer & 7 & 13.7 \\
Assistant professor & & \\
\hline
\end{tabular}

Table 2 shows the level of knowledge of faculty members about plagiarism. It could be seen that $55 \%$ of participants 
have fair knowledge about plagiarism as compared to $11.7 \%$ whom knowledge level is poor.

Table 2. Frequency distribution of faculty members' level of knowledge about plagiarism

\begin{tabular}{lll}
\hline Plagiarism knowledge & No (51) & \% \\
\hline Poor & 6 & 11.7 \\
Fair & 28 & 55 \\
Good & 17 & 33.3 \\
\hline
\end{tabular}

Note. Poor: 9-17; Fair: 18-27; Good: 28-36.

It could be seen from Table 3, that in relation to faculty members' perception of their knowledge regarding plagiarism, it changed significantly $(p=.001)$ between pre and post workshop and received $(100 \%)$ in the post workshop phase. Regarding the staff understanding of plagiarism to be wrong, again it changed significantly $(p=.012)$ with a $100 \%$ agreement post workshop. Another significant difference ( $p$ $=.001)$ was found in relation to plagiarism constituting copying from book without crediting the source with $(96.1 \%)$ of agreement in the post phase. As for faculty members' responsibility for reporting colleague's plagiarism, a significant difference ( $p=.021)$ was noted between pre and post responses and a $(94.1 \%)$ agreed to be responsible on reporting their colleague's plagiarism. Regarding the items of knowing how to avoid plagiarism and easiness of avoiding it, there were equal significant differences for both items $(p=$ $.001)$ between pre and post workshop. In relation to self plagiarism, again a significant difference $(p=.001)$ was noted between pre and post workshop responses with a percentage of $(92.2 \%)$ of disagreement after the attendance of workshop. A significant difference ( $p=.005)$ was recorded between pre and post responses as for considering copying and pasting a whole paragraph is plagiarism even if citing the reference.

As shown in Table 4, the highest percentage (96.1\%) was among those who refused plagiarism post workshop with a significant difference $(p=.001)$ between responses pre and post workshop.

Table 3. Frequency distribution and test of significance between percentage of participants' plagiarism awareness items for pre and post test

\begin{tabular}{|c|c|c|c|c|c|c|}
\hline \multirow{3}{*}{ Plagiarism item } & & \multicolumn{4}{|c|}{ Responses } & \multirow{3}{*}{$p$} \\
\hline & & \multicolumn{2}{|c|}{ Pre-test } & \multicolumn{2}{|c|}{ Post-test } & \\
\hline & & No & $\%$ & No & $\%$ & \\
\hline \multirow{2}{*}{ I know what exactly plagiarism is } & Disagree & 25 & 49.0 & - & - & \multirow{2}{*}{$.001^{*}$} \\
\hline & Agree & 26 & 51.0 & 51 & 100.0 & \\
\hline \multirow{2}{*}{ I understand plagiarism to be wrong } & Disagree & 6 & 11.8 & - & - & \multirow{2}{*}{$.012^{*}$} \\
\hline & Agree & 45 & 88.2 & 51 & 100.0 & \\
\hline \multirow{2}{*}{$\begin{array}{l}\text { Copying from a book without crediting the } \\
\text { source constitutes plagiarism }\end{array}$} & Disagree & 15 & 29.4 & 2 & 3.9 & \multirow{2}{*}{$.001 *$} \\
\hline & Agree & 36 & 70.6 & 49 & 96.1 & \\
\hline \multirow{2}{*}{ Plagiarism is a serious problem at my university } & Disagree & 8 & 17.4 & 5 & 9.8 & \multirow{2}{*}{.273} \\
\hline & Agree & 38 & 82.6 & 46 & 90.2 & \\
\hline \multirow{2}{*}{$\begin{array}{l}\text { Faculty members are responsible for reporting } \\
\text { other colleagues’ plagiarism }\end{array}$} & Disagree & 11 & 21.6 & 3 & 5.9 & \multirow{2}{*}{$.021 *$} \\
\hline & Agree & 40 & 78.4 & 48 & 94.1 & \\
\hline \multirow{2}{*}{$\begin{array}{l}\text { Faculty members perceive plagiarism to be } \\
\text { acceptable }\end{array}$} & Agree & 26 & 51.0 & 20 & 39.2 & \multirow{2}{*}{.233} \\
\hline & Disagree & 25 & 49.0 & 31 & 60.8 & \\
\hline \multirow{2}{*}{$\begin{array}{l}\text { Asking or paying someone to write a } \\
\text { paper/assignment/article for me isn't plagiarism }\end{array}$} & Agree & 9 & 17.6 & 5 & 9.8 & \multirow{2}{*}{.250} \\
\hline & Disagree & 42 & 82.4 & 46 & 90.2 & \\
\hline \multirow{2}{*}{ I know how to avoid committing plagiarism } & Disagree & 37 & 72.5 & 2 & 3.9 & \multirow{2}{*}{$.001 *$} \\
\hline & Agree & 14 & 27.5 & 49 & 96.1 & \\
\hline \multirow{2}{*}{ It is easy to avoid doing plagiarism } & Disagree & 29 & 56.9 & 6 & 11.8 & \multirow{2}{*}{$.001^{*}$} \\
\hline & Agree & 22 & 43.1 & 45 & 88.2 & \\
\hline \multirow{2}{*}{$\begin{array}{l}\text { It's ok if the writer “borrows” generously from } \\
\text { his/her previous work }\end{array}$} & Agree & 28 & 54.9 & 4 & 7.8 & \multirow{2}{*}{$.001 *$} \\
\hline & Disagree & 23 & 45.1 & 47 & 92.2 & \\
\hline \multirow{2}{*}{$\begin{array}{l}\text { Copy and paste a paragraph from other's work } \\
\text { with citing the reference isn't plagiarism }\end{array}$} & Agree & 28 & 54.9 & 14 & 27.5 & \multirow{2}{*}{$.005 *$} \\
\hline & Disagree & 23 & 45.1 & 37 & 72.5 & \\
\hline
\end{tabular}

Note. $p$ : Mc-Nemar test $* p<.05$ (significant). 
Table 4. Test of significance between pre and post workshop participants' responses in relation to the total scores of plagiarism

\begin{tabular}{|c|c|c|c|c|c|}
\hline \multirow{3}{*}{ Total score } & \multicolumn{4}{|c|}{ Phase } & \multirow{3}{*}{$p$} \\
\hline & \multicolumn{2}{|c|}{ Pre-test } & \multicolumn{2}{|c|}{ Post-test } & \\
\hline & No & $\%$ & No & $\%$ & \\
\hline Accepting plagiarism (11-27) & 21 & $41.2 \%$ & 2 & $3.9 \%$ & \multirow{2}{*}{$.001^{*}$} \\
\hline Refusing plagiarism (28-44) & 30 & $58.8 \%$ & 49 & $96.1 \%$ & \\
\hline Range & \multicolumn{2}{|c|}{$24-33$} & \multicolumn{2}{|c|}{$26-40$} & $.001 *^{\#}$ \\
\hline
\end{tabular}

Note. $p$ : Mc-Nemar test; ${ }^{\#}$ : Paired $t$-test; ${ }^{*} p<.05$ (significant).

Table 5 shows the test of significance between pre and post workshop participants' responses in relation to open ended question. It could be seen from the table that the highest percentage of participants either pre or post $(100 \%, 70.6 \%)$ respectively gave correct incomplete answer, while only (2\%) of participants responded with a complete answer, there was a significant difference $(p=.001)$ between pre and post workshop responses in relation to participants ability to define plagiarism a complete correct definition.
It could be observed from table 6 that in relation to participants' age group, the highest median of change (19.23) was among age group 40-50, while the lowest median (3.23) was recorded for the age group 30- with a significant difference between groups $(p=.002)$. Regarding the participants' titles, the highest median (20.69) was among assistant professor while the lowest median $(-1.72)$ was among clinical instructor with a significant difference recorded $(p=.050)$.

Table 5. Test of significance between pre and post workshop participants' responses in relation to open ended question

\begin{tabular}{|c|c|c|c|c|c|}
\hline \multirow{3}{*}{ Item } & \multicolumn{4}{|c|}{ Phase } & \multirow{3}{*}{$p$} \\
\hline & \multicolumn{2}{|c|}{ Pre-test } & \multicolumn{2}{|c|}{ Post-test } & \\
\hline & No & $\%$ & No & $\%$ & \\
\hline \multicolumn{6}{|l|}{ Definition of plagiarism } \\
\hline - No answer & - & - & 14 & 27.5 & \multirow{3}{*}{$.001 *$} \\
\hline - Correct incomplete answer & 51 & 100.0 & 36 & 70.6 & \\
\hline - Correct complete answer & 0 & 0.0 & 1 & 2.0 & \\
\hline \multicolumn{6}{|c|}{ Measures taken to keep away from committing plagiarism } \\
\hline - No answer & 27 & 52.9 & 26 & 51.0 & \multirow[t]{2}{*}{.843} \\
\hline - Correct incomplete answer & 24 & 47.1 & 25 & 49.0 & \\
\hline
\end{tabular}

Note. $p$ : Marginal test of homogeneity; ${ }^{*} p<.05$ (significant).

Table 6. Median value and test of significance between percentage of responses' changes between pre and post workshop in relation to demographic characteristics

\begin{tabular}{|c|c|c|c|c|c|c|}
\hline \multirow{2}{*}{ Demographic data } & \multicolumn{5}{|c|}{ Change (\%) } & \multirow{2}{*}{${ }^{\mathrm{H}} \boldsymbol{p}$} \\
\hline & Minimum & Maximum & Mean & SD & Median & \\
\hline \multicolumn{7}{|l|}{ Age (years) } \\
\hline $20-$ & -10.34 & 48.15 & 9.74 & 18.12 & 6.67 & \multirow{3}{*}{$.002 *$} \\
\hline $30-$ & -13.33 & 23.08 & 3.79 & 11.53 & 3.23 & \\
\hline $40-50$ & 0.00 & 66.67 & 21.25 & 17.10 & 19.23 & \\
\hline \multicolumn{6}{|l|}{ Title } & \multirow{6}{*}{$.050 *$} \\
\hline Clinical Instructor & -10.34 & 6.90 & -1.72 & 12.19 & -1.72 & \\
\hline Demonstrator & 6.67 & 17.24 & 11.95 & 7.48 & 11.95 & \\
\hline Assistant Lecturer & -3.13 & 48.15 & 11.86 & 18.37 & 6.54 & \\
\hline Lecturer & -13.33 & 66.67 & 14.90 & 18.79 & 12.22 & \\
\hline Assistant professor & 14.81 & 36.00 & 25.40 & 8.45 & 20.69 & \\
\hline
\end{tabular}

Note. ${ }^{\mathrm{H}} p$ : Kruskal_wallis test; ${ }^{*} p<.05$ (significant). 


\section{Discussion}

Plagiarism has been identified as a problem Since the 1600s, it has been considered as ethical problem. However, this problem is becoming more worrying with the use of internet that allows students' and researchers' easy access to plagiarism. ${ }^{[28]}$ Students have been the typical focus for researches conducted on plagiarism as the committers of unethical behaviors, and less attention has been given to academic researchers as possible contenders for such behaviors. ${ }^{[10]}$ Accordingly, the current study is conducted aiming to implement a one-day workshop to introduce the plagiarism concept as one of research misconducts and to compare between knowledge of Nursing faculty member pre and immediately post workshop.

In general, the current study's findings showed that over half of participants have fair knowledge level about plagiarism before the workshop. Plagiarism is considered a serious problem all over the world and to have a fair knowledge about it is not a good indicator for preventing plagiarism. The fair level of plagiarism knowledge could be attributed to the attendance of the faculty members to mandatory courses in order to get promoted. These courses include research ethics and international publications rules which also may include some information about plagiarism. The same was found by Ercegovac \& Richardson 2004 who stated that the cause of this finding is probably due to the concept of plagiarism itself which has several meanings based on various contexts. ${ }^{[29]}$ This result is consistent with those of Fierz \& colleagues (2014) ${ }^{[30]}$ and Broom et al. (2010) ${ }^{[31]}$ who expressed concerns about different forms of plagiarism. Findings of the current study hence, agree with studies by Introna et al. (2003), ${ }^{[32]} \mathrm{Ma}, \mathrm{Lu}$, Turner and Wan (2007) ${ }^{[33]}$ as well as Yeo (2007) ${ }^{[34]}$ who conducted their studies on students' understanding of the concept of plagiarism and stated that their level of understanding is still limited.

The current study revealed that significant changes in the level of participants' knowledge were recorded between pre and post workshop implementation. This finding could be attributed to the use of interactive teaching methodologies that enhance the participants understanding by allowing them to share in every part of the workshop either by group discussion, role play, brain storming and case study discussion. The same was found by Zein ElDin (2014) ${ }^{[35]}$ who found that interactive lecturing had a positive impact on students' learning gains.

Although most of plagiarism items differed significantly between pre and post workshop, still some responses show disagreements. As for perceiving plagiarism to be acceptable above one third of participants found it acceptable. Also, more than $10 \%$ disagreed that it is easy to avoid plagiarism. In addition to approximately one quarter of participants still agree that copy and paste a whole paragraph even with citing the reference isn't plagiarism. This result could be attributed to that the concept of plagiarism is still incomplete and vague and is also considered a new one for faculty members. Furthermore, nowadays they perceive plagiarism as a source of penalty rather than a new concept that should be considered while writing. May be faculty members are anxious as how to avoid plagiarism especially they stated many barriers to be present like; language barriers and time constraints. The same was found by Heitman et al who stated that when providing formal Responsible Conduct of Research (RCR) training, this can improve trainees' knowledge of standards, but still ensuring its effects on their practice and behaviors remains unclear. ${ }^{[36]}$ Many studies also found that faculties have a poor understanding of plagiarism. They are found to understand more examples of plagiarism but do not have the skills to discriminate with less clear-cut plagiarism scenarios. $^{[26,37,38]}$

The finding of the present study proved that the majority of participants refused plagiarism post workshop. This is a normal finding, as the plagiarism is not accepted because it is a type of theft and a clear research misconduct. During workshop, many practices were elaborated to the participants as being a kind of plagiarism, because participants had the concept that as long as they are writing the reference so it is not a plagiarism. Also, they believed that paraphrasing is only about minimum changes done in the statements and not to be rewritten by their own words. This results is consistent with those of Stes et al. (2007) $)^{[39]}$ and Lee (2011) ${ }^{[40]}$ who stressed the necessity of providing academic development initiatives including workshops and booklets to measure their impacts on faculty's academic integrity development.

The current study finding showed that after implementation of the workshop still participants were unable to give complete definition of plagiarism and nearly half of them couldn't state all measures to be taken to keep themselves away from committing plagiarism. This finding is not surprising as still the concept of plagiarism is new for them and requires more elaboration. Also, plagiarism was not introduced in their whole educational life either as students in the college or even a faculty member responsible of providing research under proper practice. The same was found by Foltýnek et al. (2013) who noted that academics struggle to identify plagiarism in particular circumstances. ${ }^{[41]}$ This study finding contradicts with those of Owunwanne et al. (2010):; ${ }^{[42]}$ Baker et al. $2008^{[43]}$ and Hochstedt et al. $(2015)^{[44]}$ who stated that faculty members have a consistent and stricter interpretation of what constitutes acceptable academic behavior. 
It was found that older participants received the highest median of change rather than the younger one with a significant difference between different age groups. On the same line, Assistant professors had the highest median of change rather than other different academic titles with a significant difference between groups. These findings could be attributed to faculty members' perceptions of the consequences and likelihood of being caught may differ during their careers as assistant professors and lectures in order to get promoted with the new bylaws, they have to check all their published articles against plagiarism and this is considered a new statement in the bylaw and at the same time increase their anxiety level for the process of promotion. The same was found by Anderson et al. (2007). ${ }^{[45]}$ On the other hand, this result contradicts with those of Martinson and colleagues $(2005)^{[46]}$ who stated that the plagiarism scores for faculty did not have significant difference among different age groups. The researchers suggested that the age of faculty members and their perceptions of plagiarism was not a predictor for or against accepting plagiarism.

\section{CONClusion AND RECOMMENDATIONS}

The current study findings concluded significant positive changes in the level of knowledge of the participants after implementation of workshop.

Based of findings, the study recommended:

(1) Introduce training program for increasing awareness of all faculty members as soon as they get recruited.

(2) Use of plagiarism detection software in order to identify the plagiarism. Accordingly, avoid it as soon as possible.

(3) Further studies that include detection of causes of plagiarism are required and measures to deal with these causes.

\section{CONFLicts OF INTEREST Disclosure}

The authors declare that there is no conflict of interest.

\section{REFERENCES}

[1] Mikesell L, Bromley E, Khodyakov D. Ethical community-engaged research: a literature review. American Journal of Public Health. 2013 Dec; 103(12): e7-14. PMid:24134352 http://dx . doi .org /10.2105/AJPH. 2013.301605

[2] Roig M. Avoiding plagiarism, self-plagiarism, and other questionable writing practices: A guide to ethical writing. August 2006. Available from: http://www.cse.msu.edu/ alexliu/plagiarism.pdf

[3] Callahan D. The cheating culture: Why more Americans are doing wrong to get ahead. Orlando, FL: Harcourt Inc; 2004.

[4] Heywood J. Assessment in higher education: Student learning, teaching, programmes and institutions. Jessica Kingsley Publishers; 2000.

[5] Judson FH. The great betrayal: Fraud in science (1st ed.). Orlando, FL: Harcourt Inc; 2004.

[6] Plagiarism. org. What is Plagiarism? Available from: http://www . plagiarism.org/plagiarism-101/what-is-plagiarism/ Accessed on April 2016.

[7] iThenticate. White paper: The ethics of self-plagiarism. 2011. Available from: http://www. ithenticate.com/resources/pa pers/ethics-of-self-plagiarism Accessed on April 2016

[8] Karabag SF, Berggren C. Retraction, dishonesty and plagiarism: analysis of a crucial issue for academic publishing, and the inadequate responses from leading journals in economics and management disciplines. Journal of Applied Economics and Business Research. 2012 Dec; 2(3): 172-83.

[9] Beisiegel U. Research integrity and publication ethics. Atherosclerosis. 2010 Oct 31; 212(2): 383-5. PMid:20692660 http://dx. doi .org $/ 10.1016 / j$. atherosclerosis .2010 .01 .050

[10] Honig B, Bedi A. The Fox in the Hen House: A Critical Examination of Plagiarism among Members of the Academy of Management. Academy of Management Learning \& Education. 2012; 11(1): 10123. http://dx.doi.org/10.5465/amle.2010.0084

[11] Macdonald R, Carroll J. Plagiarism—a complex issue requiring a holistic institutional approach. Assessment \& Evaluation in Higher
Education. 2006 Apr 1; 31(2): 233-45. http://dx.doi.org/10. 1080/02602930500262536

[12] Sutherland-Smith W. Plagiarism, the Internet, and student learning: Improving academic integrity. Routledge; 2008 Apr 24.

[13] Devlin M. Policy, preparation, and prevention: Proactive minimization of student plagiarism. Journal of Higher Education Policy and Management. 2006 Mar 1; 28(1): 45-58. http://dx.doi.org/10. 1080/13600800500283791

[14] Bedeian AG, Taylor SG, Miller AN. Management science on the credibility bubble: Cardinal sins and various misdemeanors. Management academy of Learning and Education. December 2010; 9(4): 715-725.

[15] Faculty of Health Sciences. The University of Sydney. Guide to presentation of assignments. 2013. Available from: http://sydney.edu.au/health-sciences/current-stu dents/coursework/academic-honesty-plagarism.shtml Accessed on April 2016.

[16] Anderson I. Avoiding plagiarism in academic writing. Nursing Standard. 2009; 23(18): 35-7. http://dx.doi.org/10.7748/ns. 23 $.18 .35 . \mathrm{s} 51$

[17] Fanelli D. How many scientists fabricate and falsify research? A systematic review and meta-analysis of survey data. PloS One. 2009 May 29; 4(5): e573. PMid:19478950 http://dx.doi.org/10.13 71/journal pone. 0005738

[18] Broome M, Dougherty MC, Freda MC, et al. Ethical concerns of nursing reviewers: An international survey. Nursing ethics. $2010 \mathrm{Nov}$ 1; 17(6): 741-8. PMid:21097972 http://dx.doi.org/10.1371 /journal.pone. 0005738

[19] Belal A, Springuel I. Reseearch in Egyptian Universities: The role of research in higher education. 2006. Available from: http://portal .unesco.org/education/fr/files/51625/1 1634283255Springuel-EN.pdf/Springuel-EN.pdf Accessed on April 2016 
[20] Darrag M, Yousri DM, Badreldin A. Academic Dishonesty in Egypt: A Nation-wide study of students in Higher Education. May 2012. Available from: http://mgt.guc.edu.eg/wpapers/031darrag _yousri_badreldin2012.pdfAccessedonApril2016

[21] Al-Masry Al-Youm. Academic: Egypt among highest in research plagiarism. Available from: http: //www.egyptindependent.com/news/academic-egypt - among-highest-research-plagiarism

[22] Elyan T. The top-down effect: Plagiarism in Egyptian universities. Daily News Egypt. 3 July 2008. Available from: http://www.ma sress.com/en/dailynews/114024

[23] Khaled A. EGYPT: Research plagued by plagiarism. The University World News. 20 July 2008. Available from: http://www . universityworldnews. com/article.php? story $=20080717165104870$

[24] Supreme council of universities. The system for faculties' promotion. Available from: http://staffmemprom.scu.eg: 9080/MIS/faces/homepage. jsf ?faces-redirect=true\&_ adf . $\operatorname{ctrl}-$ state $=1 \mathrm{dbf} 3 \mathrm{v} 7 \mathrm{t} 6 \mathrm{z}_{-} 3$

[25] Simon S, Cook B, Minichiello M, et al. Academic integrity: differences between design assessments and essays. Available from: http://www.drs2014.org/media/654194/0231-file1.pdf

[26] The Higher Education Academy JISC Academic Integrity Service. Supporting academic integrity: Approaches and resources for higher education. Available from: http://www2.wlv.ac.uk/celt/ho wto/SupportingAcademicIntegrity.pdf

[27] Gullifer J, Tyson GA. Exploring university students' perceptions of plagiarism: A focus group study. Studies in Higher Education. 2010 Jun 1; 35(4): 463-8. Available from: http://www.tup.com.cn /upload/books/yz/052607-01.pdf http://dx.doi.org/10. 1080/03075070903096508

[28] Ali WZ, Ismail H, Cheat TT. Plagiarism: to what extent it is understood? Procedia-Social and Behavioral Sciences. 2012; 59: 604-11. http://dx.doi.org/10.1016/j.sbspro.2012.09.320

[29] Ercegovac Z, Richardson JVJr. Academic dishonesty, plagiarism included, in the digital age: A literature review. College \& Research Libraries. 2004 July; 301-18. Available from: http://crl .acrl.o $\mathrm{rg} /$ content/65/4/301.full.pdf+html http://dx.doi.org $/ 10.5860 /$ crl.65.4.301

[30] Fierz K, Gennaro S, Dierickx K, et al. Morin, Sabina De Geest. Scientific misconduct: Also an issue in Nursing Science. Journal of Nursing Scholarship. 2014; 46(4): 271-80. PMid:24758524 http://dx.doi.org/10.1111/jnu.12082

[31] Broom ME, Dougherty MC, Freda MC, et al. Ethical concerns of nursing reviewers: An international survey. Nursing Ethics. 2010 17(6): 741-748. PMid:21097972 http://dx.doi.org/10.1177 /0969733010379177

[32] Introna L, Hayes N, Blair L, et al. Cultural attitudes towards plagiarism. 2003. Lancaster: University of Lancaster. Available from: http://citeseerx.ist.psu.edu/viewdoc/download ?rep=rep1\&type=pdf\&doi=10.1.1.210.6903

[33] Ma HJ, Lu E, Turner S, et al. An empirical investigation of digital cheating and plagiarism among middle school students. American Secondary Education. 2007; 35(2): 69-82. Available from: http://search.ebscohost.com/login.aspx?direct $=$ true $\& \mathrm{db}=a 3 \mathrm{~h} \& \mathrm{AN}=24895456 \&$ site $=$ ehost - live
[34] Yeo S. First-year university science and engineering students' understanding of plagiarism. Higher Education Research \& Development. 2007; 26(2): 199-216. Available from: http:// www. inf ormaworld.com/10.1080/07294360701310813 http: //dx.doi.org/10.1080/07294360701310813

[35] Zein ElDin Y. Implementing Interactive Nursing Administration lectures and identifying its influence on students' learning gains. Journal of Nursing Education and Practice. 2014; 4(5): 107-115. http://dx.doi.org/10.5430/jnep.v4n5p107

[36] Heitman E, Anestidou L, Olsen C, et al. Do researchers tend to overlook misbehavior? Hastings Cent Rep. 2005; 35: 49. http: //dx.doi.org/10.2307/3528335

[37] Gynnild V, Gotschalk P. Promoting academic integrity at a Midwestern University: Critical review and current challenges. International Journal for Educational Integrity. 2008 Dec 11; 4(2): 41-59. Available from: http://www.ojs.unisa.edu.au/index.php/IJEI/ article/view/413/293

[38] Curtis GJ, Popal R. An examination of factors related to plagiarism and a five-year follow-up of plagiarism at an Australian university International Journal for Educational Integrity. 2011; 7(1): 30-42.

[39] Stes A, Clement M, Van Petegem P. The effectiveness of a faculty training programme: Long-term and institutional impact. International Journal for Academic Development. 2007; 12(2): 99-109. http://dx.doi.org/10.1080/13601440701604898

[40] Lee JKW, Partridge L. Evaluating the effectiveness of educational and academic integrity initiatives in higher education. 2011. In Educational integrity: Culture and values. Proceedings 5th Asia Pacific Conference on Educational Integrity. The University of Western Australia, 26-28 September. (pp. 82-86) Available from: http://www . apcei.catl . uwa.edu. au/procs/lee.pdf

[41] Foltýnek T, Rybička J, Demoliou C. Do students think what teachers think about plagiarism? 2013. Available from: http://www.ojs . unisa.edu.au/index.php/IJEI/article/view/931/654

[42] Owunwanne D, Rustagi N, Dada R. Students' Perceptions of Cheating and Plagiarism in Higher Institutions. Journal of College Teaching and Learning. Nov. 2012; 7(11): 59-68.

[43] Baker RK, Berry P, Thornton B. Student Attitudes on Academic Integrity Violations. Journal of College Teaching \& Learning. January 2008; 5(1); 5-13.

[44] Hochstedt K, Zappe S, Litzinger T, et al. The impact of faculty development workshop on students' understanding of academic integrity. In122nd American Society of Engineering Education Annual Conference \& Exposition. Seattle, WA 2015. Available from: https://scholar.google.com.eg/scholar?q=The+impact +of +faculty+development+workshop+on+students $\% \mathrm{E} 2 \% 80$ $\% 99+$ understanding+of+academic+integrity.\&hl=en\&as_

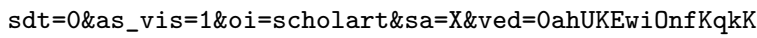
rMAhXBnBoKHdUuDOsQgQMIGDAA

[45] Anderson MS, Horn AS, Risbey KR, et al. What do mentoring and training in the responsible conduct of research have to do with scientists' misbehavior? Findings from a national survey of NIHfunded scientists. Academic Medicine. 2007 Sep 1; 82(9): 85360. PMid:17726390 http://dx.doi.org/10.1097/ACM. 0 b013 e31812f764c

[46] Martinson B, Anderson M, Vries R. Scientists behaving badly. Nature. 2005; 435(9): 737-8. Available from: http://www. natu re.com/nature/journal/v435/n7043/full/435737a.html PMid:15944677 http://dx.doi.org/10.1038/435737a 